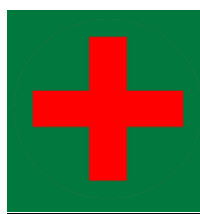

\title{
Tinjauan Lama Waktu Penyediaan Rekam Medis Rawat Jalan Di Rumah Sakit Anna Medika Bekasi
}

\author{
Winda Febriarini ${ }^{1}$, Puteri Fannya ${ }^{2}$, Nanda Rumana ${ }^{3}$, Noor Yulia ${ }^{4}$ \\ 1,2,3,4 Program Studi Rekam Medis dan Informasi Kesehatan, Fakultas Ilmu-ilmu \\ Kesehatan, Universitas Esa Unggul, DKI Jakarta, Indonesia \\ E-mail : ${ }^{1}$ windafebri013@gmail.com
}

\begin{abstract}
In the provision of medical record files in hospitals, it is one indicator of patient satisfaction whose time has been determined in accordance with the hospital's minimum service standards, the standard for the time of providing medical record documents for outpatient services is less than or equal to 10 minutes. 10 minutes), while the time for providing inpatient medical record documents is less than or equal to 15 minutes ( 15 minutes). The purpose of the study was to determine the length of time for providing outpatient medical records at Anna Medika Hospital Bekasi. The research method uses a descriptive method with a quantitative approach, the population of outpatient medical record files visiting the hospital, the sample studied is 106 files, through observation, interviews and time measurement records in the timely provision of medical records so that researchers get research results. The results of the study found that 59 (55.66\%) medical records were provided on time and 47 (44.34\%) medical records were not provided on time. Factors causing the length of time of provision > 10 minutes are errors in storing medical records, full storage shelves, lack of competence of medical record officers. Suggestions can improve the quality of service and the speed of time for providing medical records and holding standard operating procedures (spo) regarding the provision of medical records.
\end{abstract}

Keyword: Medical Records, Minimum Service Standards, Time of Provision.

\begin{abstract}
Abstrak
Dalam penyediaan berkas rekam medis dirumah sakit merupakan salah satu indikator kepuasan pasien yang telah ditetapkan waktunya sesuai dengan standar pelayanan mininal rumah sakit, standar untuk waktu penyediaan dokumen rekam medis pelayanan rawat jalan kurang dari atau sama dengan 10 menit( $\leq 10$ menit $)$, sedangkan untuk waktu penyediaan dokumen rekam medis pasien rawat inap kurang dari atau sama dengan 15 menit ( $\leq 15$ menit). Tujuan dari penelitian adalah untuk mengetahui lama waktu penyediaan rekam medis rawat jalan di Rumah Sakit Anna Medika Bekasi. Metode penelitian menggunakan metode deskriptif dengan pendekatan kuantitatif, populasi berkas rekam medis pasien rawat jalan yang berkunjung di rumah sakit, sampel yang diteliti adalah 106 berkas, melalui observasi, wawancara dan catatan pengukuran waktu dalam ketepatan waktu penyediaan rekam medis sehingga peneliti mendapatkan hasil penelitian. Hasil penelitian ditemukan penyediaan berkas rekam medis tepat waktu sebanyak $59(55,66 \%)$ rekam medis dan yang tidak tepat waktu sebanyak 47 $(44,34 \%)$ rekam medis. Faktor penyebab lama waktu penyediaan $>10$ menit ialah salah
\end{abstract}


dalam penyimpanan rekam medis, rak penyimpanan penuh, kurangnya kompetensi petugas rekam medis. Saran dapat meningkatkan mutu pelayanan dan kecepatan waktu penyediaan rekam medis serta mengadakan standar prosedur operasional (spo) tentang penyediaan rekam medis.

Kata Kunci : rekam medis, standar pelayanan minimal, waktu penyediaan

\section{PENDAHULUAN}

Rumah sakit adalah institusi pelayanan kesehatan yang menyelenggarakan pelayanan kesehatan perorangan secara paripurna yang menyediakan pelayanan rawat inap, rawat jalan, dan gawat darurat. Rumah sakit didirikan dan dijalankan dengan tujuan memberikan pelayanan kesehatan dalam bentuk perawatan, pemeriksaan, pengobatan dan tindakan diagnosis lainnya yang dibutuhkan oleh masing-masing pasien dalam batas-batas kemampuan teknologi dan sarana yang disediakan dirumah sakit (Pemerintah RI, 2009). Rumah sakit sebagai salah satu sarana pelayanan kesehatan yang melakukan pelayanan rawat jalan maupun rawat inap wajib membuat rekam medis. Pengisian dokumen rekam medis dilakukan oleh dokter dan tenaga kesehatan lainnya.

Menurut Peraturan Menteri Kesehatan RI No. 269/ Menkes/Per/III/2008 rekam medis adalah berkas yang berisikan catatan dan dokumen tentang identitas pasien, pemeriksaan, pengobatan, tindakan dan pelayanan lain yang telah diberikan kepada pasien (Permenkes RI, 2008). Agar rekam medis dapat digunakan dengan baik maka suatu rumah sakit harus melakukan penyelenggaraan rekam medis. Penyelenggaraan rekam medis di rumah sakit antara lain pendaftaran, penyimpanan dan pengolahan data rekam medis. Pendaftaran pasien di rumah sakit dibagi menjadi beberapa bagian antara lain pendaftaran pasien rawat jalan, pendaftaran pasien rawat inap dan pendaftaran pasien gawat darurat. waktu tunggu dalam pelayanan rawat jalan menjadi salah satu indikator kepuasan pasien yang akan mempengaruhi mutu pelayanan di rumah sakit (Torry et al., 2016). Dalam penyediaan berkas rekam medis yang merupakan salah satu indikator kepuasan pasien yang telah ditetapkan waktunya sesuai dengan standar pelayanan mininal.

Menurut Surat Keputusan Mentri Kesehatan RI no 129 Tahun 2008 tentang Standar Pelayanan Minimal menyebutkan salah satu indikator mutu pelayanan rawat jalan yaitu waktu tunggu di rawat jalan. Kemenkes RI juga menentukan indikator standar untuk waktu penyediaan dokumen rekam medis pelayanan rawat jalan kurang dari atau sama dengan 10 menit ( $\leq 10$ menit ), sedangkan untuk waktu penyediaan dokumen rekam medis pasien rawat inap kurang dari atau sama dengan 15 menit $(\leq 15$ menit) (Kemenkes RI, 2008).

Dalam hasil penelitian Sudrajat \& Sugiarti di Rumah Sakit Umum Daerah Ciamis bahwa kecepatan penyediaan dokumen rekam medis pasien lama di pelayanan rawat jalan dengan jumlah penyediaan dokumen yang cepat sebanyak 35 dokumen $(39,77 \%)$ dan penyediaan dokumen rekam medis yang lambat sebanyak 53 dokumen $(60,23 \%)$ dari jumlah sampel 88 , dan diketahui rata-rata penyediaan dokumen rekam medis sekitar 20 menit (Sudrajat \& Sugiarti, 2015). Kemudian dalam penelitian Supriadi \& Damayanti menyebutkan jika ditemukan sebanyak 144 atau $60 \%$ dari berkas rekam medis dengan waktu penyediaan $\leq \leq 10$ menit sedangkan 98 atau $40 \%$ berkas rekam medis memerlukan waktu penyediaan > 10 menit (Supriadi \& Damayanti, 2019). 
Di Rumah Sakit Anna Medika yang berada di daerah Bekasi merupakan rumah sakit kedua dari jaringan rumah sakit dan klinik di bawah naungan Anna Group. Beropreasi mulai pada tanggal 10 Februari 2010. Rumah Sakit Anna Medika merupakan Rumah Sakit Tipe C berkapasitas 140 tempat tidur dilengkapi dengan sarana penunjang yang lengkap terutama untuk perawatan usia dewasa maupun anak.

Setelah melakukan observasi tentang waktu penyediaan di Rumah Sakit Anna Medika Bekasi masih ditemukan ketidaktepatan waktu dalam penyediaan rekam medis pasien ke pelayanan rawat jalan di Rumah Sakit Anna Medika Bekasi. Dalam penyediaan rekam medis rawat jalan peneliti mengobservasi 25 rekam medis. Ditemukan $13(52 \%)$ rekam medis yang waktu penyediaan rekam medisnya $>10$ menit dan ada $12(48 \%)$ rekam medis waktu penyediaannya $\leq 10$ menit, penyediaan rekam medis yang terlambat sehingga membuat pasien menunggu untuk mendapatkan pelayanan. Sementara Kemenkes RI telah menentukan standar waktu penyediaan rekam medis pelayanan rawat jalan selama 10 menit (Kemenkes RI, 2008).

Tujuan dari penelitian ini ialah untuk mengetahui lama waktu penyediaan rekam medis rawat jalan dan juga mengetahui penyebab terjadinya lama waktu penyediaan rekam medis di Rumah Sakit Anna Medika.

\section{METODE}

Penelitian ini merupakan penelitian deskriptif pendekatan kuantitatif yang dilakukan untuk memberikan gambaran, mengukur dan melihat langsung suatu keadaan saat penyediaan berkas rekam medis pasien rawat jalan yang dilakukan di dalam unit rekam medis. Informan untuk penelitian ini adalah Kepala Unit Rekam Medis dan mengamati petugas rekam medis rawat jalan. Dalam pengumpalan data dilakukan dengan metode observasi (pengamatan) dan wawancara. Instrumen penelitian yang digunakan ialah pedoman wawancara, stopwatch dan data checklist. Populasi yang digunakan berkas rekam medis pasien rawat jalan yang berkunjung di Rumah Sakit Anna Medika Bekasi. Jumlah sampel yang dietliti adalah 106 berkas rekam medis.

\section{HASIL}

\section{Mengidentifikasi Standar Prosedur Operasional Penyediaan Rekam Medis Rawat Jalan di Rumah Sakit Anna Medika Bekasi}

Berdasarkan hasil observasi saat turun lapangan kegiatan petugas rekam medis dalam menyediakan berkas rekam medis yaitu, pertama petugas pendaftaran mendaftarkan pasien sampai Cash Slip/Bon Pembayaran tercetak, kemudian petugas pendaftaran meletakan Cash Slip itu pada keranjang yang telah disipakan, petugas mengambil Cash Silp/ Bon Pembayaran beserta formulir rawat jalan/IGD bila pasien baru, kemudian di buat rekam medis jika pasien baru dan mencari berkas rekam medis jika itu pasien lama hingga berkas tersebut tersedia. Penulis mengusulkan untuk membuat standar prosedur operasional tersendiri untuk penyediaan rekam medis. 


\section{Menghitung Lama Waktu Penyediaan Rekam Medis Rawat Jalan di Rumah Sakit Anna Medika Bekasi}

Penyediaan rekam medis merupakan tugas dari petugas bagian filling/penyimpanan, waktu penyediaan berkas rekam medis pasien rawat jalan dihitung dari cash slip/bon pembayaran yang keluar kemudian diserahkan kebagian unit rekam medis untuk dicari berkas rekam medisnya hingga rekam medis tersebut tersedia..

Dalam hasil penelitian rata rata lama waktu penyediaan rekam medis pasien rawat jalan di Rumah Sakit Anna Medika pada bulan Juni 2021.

Tabel 1. Waktu Penyediaan Berkas Rekam Medis Pasien Rawat Jalan di Rumah Sakit Anna Medika Bekasi

\begin{tabular}{lcc}
\hline \hline $\begin{array}{c}\text { Ketepatan Waktu Penyediaan } \\
\text { Rekam medis }\end{array}$ & $\begin{array}{c}\text { Frekuensi } \\
\text { Berkas }\end{array}$ & Persentase \% \\
\hline Tepat Waktu & 59 & $55,66 \%$ \\
\hline Tidak Tepat Waktu & 47 & $44,34 \%$ \\
\hline \multicolumn{1}{c}{ Total } & 106 & $100 \%$ \\
\hline $\begin{array}{c}\text { Rata - rata lama waktu rekam } \\
\text { medis tersedia }\end{array}$ & \multicolumn{2}{c}{8,83 menit } \\
\hline \hline
\end{tabular}

Berdasarkan tabel diatas menjelaskan bahwa frekuensi ketepatan dalam penyediaan berkas rekam medis tepat waktu 59 rekam medis sebanyak 55,66\% dan untuk waktu penyediaan berkas rekam medis yang tidak tepat waktu 47 rekam medis sebanyak 44,34\% dengan sampel 106 berkas rekam medis rata rata waktu pasien menunggu adalah 8 menit 83 detik.

\section{Mengidentifikasi Faktor - Faktor Yang Menyebabkan Keterlambatan Dalam Penyediaan Rekam Medis Rawat Jalan di Rumah Sakit Anna Medika Bekasi}

Berdasarkan hasil perhitungan ketepatan waktu penyediaan berkas rekam medis pasien rawat jalan, waktu penyediaan rekam medis yang tidak tepat waktu persentase nya sebesar $44,34 \%$, hal ini dikarenakan adanya faktor faktor yang menyababkan keterlambatan dalam penyediaan rekam medis yaitu: missfile, keterlambatan penyerahan cash slip/ bon pembayaran. Kapasitas rak penyimpanan penuh. Kurangnya kompetensi petugas rekam medis.

\section{PEMBAHASAN}

\section{Mengidentifikasi Standar Prosedur Operasional Penyediaan Rekam Medis Rawat Jalan di Rumah Sakit Anna Medika Bekasi}

Dalam hasil wawancara dengan Kepala Instalasi Rekam Medis di Rumah Sakit Anna Medika, diketahui untuk standar prosedur operasional penyediaan rekam medis belum tersedia, tetapi untuk standar prosedur peminjaman rekam medis sudah tersedia. Standar Prosedur Operasional diharuskan tetap ada, supaya dapat menjadi pedoman bagi para petugas yang berhubungan dengan pelaksanaan penyediaan rekam medis 
rawat jalan agar petugas menjadi lebih patuh dalam menyediakan rekam medis $<10$ menit (Amalia et al., 2020). Dalam penelitian Indah Kristina dkk (2015), disebutkan untuk standar prosedur operasional khusus tentang penyediaan berkas rekam medis tidak ada, namun pelaksanaannya mengacu pada ketentuan SPM yang telah ditetapkan pemerintah(Kristina et al., 2015).

\section{Menghitung Lama Waktu Penyediaan Rekam Medis Rawat Jalan di Rumah Sakit Anna Medika Bekasi}

Berdasarkan tabel 1 menjelaskan bahwa frekuensi ketepatan dalam penyediaan berkas rekam medis tepat waktu 59 rekam medis sebanyak 55,66\% dan untuk waktu penyediaan berkas rekam medis yang tidak tepat waktu 47 rekam medis sebanyak 44,34\% dengan sampel 106 berkas rekam medis rata rata waktu pasien menunggu adalah 8 menit 83 detik.

Dalam penyediaan berkas rekam medis pasien rawat jalan dilakukan sesuai dengan standar waktu penyediaannya $\leq 10$ menit. Penyediaan rekam medis merupakan tugas dari petugas bagian filling/penyimpanan, waktu penyediaan berkas rekam medis pasien rawat jalan dihitung dari cash slip/bon pembayaran yang keluar kemudian diserahkan kebagian unit rekam medis untuk dicari berkas rekam medisnya. Hasil pengamatan yang peneliti dapat di Rumah Sakit Anna Medika Bekasi, waktu penyediaan rekam medis masih menunjukan adanya keterlambatan penyediaan rekam medis rawat jalan di Rumah Sakit Anna Medika, persentase yang diamati dari 106 sampel data rekam medis ditemukan 59 rekam medis tersedia 10 menit dan ada 47 rekam medis penyediaannya $>10$ menit, sedangkan menurut Standar Pelayanan Minimal waktu penyedian rekam medis rawat jalan adalah $\leq 10$ menit (Kemenkes RI, 2008).

\section{Mengidentifikasi Faktor - Faktor Yang Menyebabkan Keterlambatan Dalam Penyediaan Rekam Medis Rawat Jalan di Rumah Sakit Anna Medika Bekasi}

\section{Missfile}

Terjadinya Missfile atau salah simpan adalah salah satu faktor penyebab keterlambatan penyediaan berkas rekam medis, petugas harus menyisir satu per satu berkas rekam medis, dan berkas rekam medis yang salah dalam penyimpanannya, jadi rekam medis sering terselip didalam rak rekam medis rawat inap karena kesalahan dalam penempatan berkas secara sistem penomoran berkas. Berdasarkan wawancara dengan petugas yaitu:

\footnotetext{
"Iya dek, sering terlambat ya karna kebanyakan misfile, kalau ga ada dirawat jalan (rak penyimpanan) pasti kita cari dirawat inap sampai ketemu”
}

Petugas A

Selain itu terdapat juga kesalahan dalam menyimpan rekam medis dan faktor sistem penomoran dalam rak penyimpanan yang menyebabkan berkas terselip sulit ditemukan oleh petugas. Sistem penomoran yang digunakan di Rumah Sakit Anna Medika ada 2(dua) yaitu Sistem Nomor langsung untuk rak penyimpanan rawat inap 
dan Sistem Terminal Digit untuk rak penyimpanan rawat jalan yang berfokus pada 2 gidit terakhir pada nomor rekam medis. Kekurangan dalam menggunakan sistem terminal digit ini petugas lebih sulit mempelajari (Widjaja \& Dewi, 2016). Dalam penelitian yang ditulis oleh Wati et al, penjajarannya menggunlana Terminal Digit Filling (TDF) tetapi masih terdapat kesalahan letak dalam penyimpanan dan penjajaran dokumen rekam medis ke rak penyimpanan missfile (Wati et al., 2011).

\section{Keterlambatan Penyerahan Cash Slip/ Bon Pembayaran}

Dalam cash slip/bon pembaran yang berisi : nomor rekam medis, identitas pasien, jenis pembayaran. Terjadi keterlambatan penyerahan cash slip karena petugas pendaftaran, petugas pendaftaran mengumpulkan cash slip tersebut hingga terkumpul banyak baru cash slip akan diberikan kebagian rekam medis melalui keranjang dan salah satu yang menyebabkan lama penyediaan berkas rekam medis. Berdasarkan wawancara dengan petugas yaitu:

“ Kadang yang buat kita lama buat nyari bekas itu.... karna cash slipnya belum dikasih kekita, soalnya bagian pendaftaran kadang ngumpulin sampe banyak dulu baru kita cari"

Petugas B

Dalam hal ini juga disampaikan pada penelitian yang dilakukan Supriadi dan Damayanti, yang mengakatakan bukti transaksi yang dijadikan tracer sering tercecer dan hilang sehingga sulit saat melakukan pencarian berkas rekam medis yang dibutuhkan (Supriadi \& Damayanti, 2019). Penelitian yang dilakukan oleh Dewi Kotimah juga menyebutkan faktor yang mempengaruhi keterlambatan penyediaan rekam medis ialah tracer setelah dicetak seharusnya langsung dinaikkan, namun masih dibiarkan dibawah sampai menumpuk, dan pada bagian bagian filling berkas rekam medis juga tidak dikirim langsung tetapi menunggu berkas rekam medis tersebut penuh (Kotimah, 2017).

\section{Kapasitas Rak Penyimpanan Penuh}

Berkas rekam medis yang tercecer akibat rak penyimpanan rekam medis penuh, sebagian berkas diletakan didalam kardus karna rak penyimpanan belum cukup menampung rekam medis. Berdasarkan wawancara dengan petugas yaitu:

"Rak penyimpanan penuh, karna kita belum ngelakuin retensi lagi dek, ..iyaa terakhir kita ngelakuin tahun 2017, dan sampe sekarang kita belum musnahin berkas juga karna kita belum ada scan-an buat nyimpen berkas yang penting, jadi yang lama lama (berkas rekam medis) kita taro diatas, tumpuk tumpuk kardus gitu.."

Petugas A

“ Kita belum melakukan retensi karna kurang Dana SDM juga Petugas SDM nya, ...Iya dana buat petugas lemburnya"

Kepala Unit Rekam Medis 
Berdasarkan hasil wawancara mengatakan di Rumah Sakit Anna Medika terakhir melakasanakan retensi pada tahun 2017 dan belum melakukan pemusnahan dari tahun 2010 sampai tahun ini dikarenakan keterbatasan Sumber Daya Manusia dan dana Sumber Daya Manusia. Dalam Peraturan Menteri Kesehatan RI disebutkan rekam medis disimpan sekurang- kurangnya untuk jangka waktu 5 (lima) tahun terhitung dari tanggal terakhir pasien berobat ke rumah sakit (Permenkes RI, 2008). Pada penelitian yang dilakukan oleh Aprilia (2020), mengatakan bahwa dalam kurangnya rak penyimpanan untuk rekam medis di Rumah Sakit Husada Utama Surabaya, dikarenakan setiap harinya pasien akan bertambah dan berkas rekam medis banyak yang disimpan tidak pada rak filling karena sudah tidak muat, sehingga perlu penambahan rak untuk berkas rekam medis (Aprilia, 2020).

\section{Kurangnya Kompetensi Petugas Rekam Medis}

Kurangnya kompetensi petugas rekam medis, dalam pengetahuan terhadap penyelenggaraan di unit rekam medis karena kepala rekam medis tidak membuat pelatihan khususnya untuk petugas penyediaan. Berdasarkan wawancara dengan Kepala Rekam Medis dan petugas yaitu:

"Kalau dirumah sakit, khusus bagian rekam medis ga ada pelatihannya win, kalau ada yang ngelamar kerja juga langsung wawancara aja sama aku, ... kalau untuk petugas sekarang untuk masuk direkam medis bagian yang nyiapin sih tamatan SMA juga bisa ngelamar yang penting jujur terus teliti aja"

Kepala Unit Rekam Medis

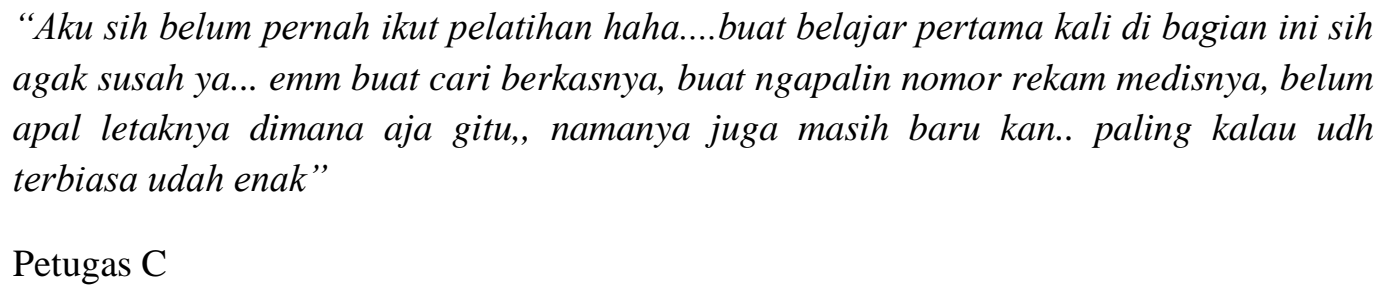
agak susah ya... emm buat cari berkasnya, buat ngapalin nomor rekam medisnya, belum apal letaknya dimana aja gitu,, namanya juga masih baru kan.. paling kalau udh terbiasa udah enak"

Petugas C

Berdasarkan hasil wawancara, dalam unit rekam medis di Rumah Sakit Anna Medika Bekasi khususnya petugas penyediaan rekam medis juga tidak diadakan pelatihan, dan dalam kualifikasi pendidikan belum sesuai dengan standar yang telah ditentukan, dimana pegawai rekam medis harus memiliki kualifikasi pendidikan formal minimal DIII rekam medis (Permenkes RI, 2013). Dalam hal ini juga sejalan dengan penelitian yang dilakukan oleh Sari dan Trisna, petugas rekam medis yang belum pernah mengikuti pelatihan terutama bagi petugas rekam medis yang tidak memiliki basic rekam medis, sehingga petugas tidak memiliki wawasan yang berkembang tentang rekam medis dan tidak memiliki pengetahuan cukup tentang rekam medis (Sari \& Trisna, 2019). 


\section{KESIMPULAN DAN SARAN}

Berdasarkan hasil dan pembahasan terhadap tinjauan lama waktu penyediaan rekam medis rawat jalan di Rumah Sakit Anna Medika Bekasi, dapat disimpulkan : di Rumah Sakit Anna Medika Bekasi masih mengalami ketidaktepatan waktu penyediaan berkas rekam medis, penyediaan berkas rekam medis yang >10 menit $47(44,34 \%)$ berkas, dan yang ketepatan waktunya kurang lebih sama dengan $<10$ menit $59(55,66 \%)$ berkas. dengan tidak adanya standar prosedur operasional (spo) tentang penyediaan rekam medis rawat jalan petugas tidak dapat berjalan sesuai dengan standar peraturan yang ada, dan dapat mempengaruhi kualitas pelayanan rekam medis dirumah sakit. Faktor-faktor yang menjadi penyebab terjadinya keterlambatan penyedian rekam medis yaitu, Missfile, Keterlambatan oenyerahan Cash Slip, Kapasitas rak penyimpanan penuh, dan Kurangnya kualitas petugas rekam medis.

\section{DAFTAR PUSTAKA}

Amalia, P. L.; Santi, S. M. W., \& Adi, W. R. (2020). Analisis Faktor Penyebab Keterlambatan Penyediaan Dokumen Rekam Medis Rawat Jalan di RSU Haji Surabaya. 1(3), 288-296.

Aprilia, A. K. D. (2020). Identifikasi Penyebab Keterlambatan Penyediaan Dokumen Rekam Medis Rawat Jalan di Rumah Sakit Husada Utama Surabaya Tahun 2020. J-REMI: Jurnal Rekam Medik Dan Informasi Kesehatan, 1(4), 630-638. https://publikasi.polije.ac.id/index.php/j-remi/article/view/2130/pdf

Kemenkes RI. (2008). Peraturan 129/Menkes/SK/II/2008. STANDAR PELAYANAN MINIMAL RUMAH SAKIT, 49(95), 980.

Kotimah, D. (2017). WAKTU PENYEDIAAN DOKUMEN REKAM MEDIS RAWAT JALAN DI RSUD WATES TAHUN 2017. WAKTU PENYEDIAAN DOKUMEN REKAM MEDIS RAWAT JALAN DI RSUD WATES TAHUN 2017, 87(1,2), 149200.

Kristina, I., Ambarwati, \& Putra, Y. S. (2015). Tinjauan Waktu Penyediaan Rekam Medis Pelayanan Rawat Jalan di Rumah Sakit Islam Jakarta Pondok Kopi. Medicordhif Journal, 2(1), 28-40.

Pemerintah RI. (2009). Undang-Undang Republik Indonesia. No. 44 Tahun 2009 Tentang Rumah Sakit, 2009(75), 31-47.

Permenkes RI. (2008). PMK Nomor 269/MENKES/PER/III/2008 Tentang Rekam Medis. In Peraturan Menteri Kesehatan tentang Rekam Medis (hal. 7).

Permenkes RI. (2013). PERMENKES RI NOMOR 55 TAHUN 2013. Penyelenggaraan Pekerjaan Perekam Medis, 369(1), 1689-1699. file:///C:/Users/Smile/Downloads/manajemen sumber daya manusia ( PDFDrive.com ).pdf

Sari, T. P., \& Trisna, W. V. (2019). Analisis Pengetahuan Petugas Rekam Medis Tentang Terminologi Medis dI RSUD Petala Bumi Provinsi Riau. Jurnal Manajemen Informasi Kesehatan Indonesia, 7(1), 64. https://doi.org/10.33560/jmiki.v7i1.206 
Sudrajat, I., \& Sugiarti, I. (2015). Hubungan Kecepata N Penyediaan Dokumen Rekam Medis Rawat Jalan Dengan Tingkat Kepuasan Pasien. Jurnal Manajemen Informasi Kesehatan Indonesia, 3(1). https://doi.org/10.33560/.v3i1.73

Supriadi, \& Damayanti, D. P. (2019). Tinjauan Waktu Penyediaan Berkas Rekam Medik Rawat Jalan Rumah Sakit X di Tangerang Selatan. Jurnal Administrasi Bisnis Terapan, 2(1), 1-8. https://doi.org/10.7454/jabt.v2i1.68

Torry, T., Koeswo, M., \& Sujianto, S. (2016). Faktor yang Mempengaruhi Waktu Tunggu Pelayanan Kesehatan kaitannya dengan Kepuasan Pasien Rawat Jalan Klinik penyakit dalam RSUD Dr. Iskak Tulungagung. Jurnal Kedokteran Brawijaya, 29(3), 252-257. https://doi.org/10.21776/ub.jkb.2016.029.03.3

Wati, O. M., Pujihastuti, A., \& Riyoko. (2011). Tinjauan Pelaksanaan Penyimpanan dan Penjajaran Dokumen Rekam Medis di Ruang Filling RSUD Dr MOEWARDI. Jurnal Kesehatan, V(2), 20-28.

Widjaja, L., \& Dewi, D. (2016). Manajemen Informasi Kesehatan II : Sistem dan Sub Sistem Pelayanan RMIK. 4(1), 64-75. 